\title{
O caráter pedagógico da I Carta de São Clemente Romano aos Coríntios
}

\section{The Pedagogical Caracter in the Letter of Clement of Roman to the Corinthians}

\author{
Marcia Elieder Bolonhez Meneguetti ${ }^{1 *}$, Roseli Gall do Amaral da Silva ${ }^{2}$, Prof. Dr. José \\ Joaquim Pereira Melo ${ }^{1}$,
}

\begin{abstract}
RESUMO
Este artigo tem a finalidade de demonstrar o caráter pedagógico que emerge da I Carta de Clemente Romano aos Coríntios, no século I d.C. no que diz respeito às virtudes que este bispo de Roma defendeu para a formação ideal cristã. Clemente Romano, terceiro bispo de Roma, ao receber notícias de dissidências na comunidade de Corinto, resolveu escrever esta carta para emitir conselhos e diretrizes para os fieis desta comunidade cristã e, na tentativa de conseguir convencê-los a dirimirem os problemas de relacionamento elaborou um manual destacando virtudes essenciais a formação do homem cristão do período. Em sua carta, pode-se observar exemplos de amor ao próximo, a humildade, a fé, a obediência, a fraternidade, a união e a disciplina. Estas virtudes são explanadas na carta de uma forma educativa, utilizando recursos pedagógicos, para que esses seguidores da nova crença cristã obtivessem referências comportamentais e, também se tornassem exemplo para novos adeptos.
\end{abstract}

Palavras-chave: Educação; Cristianismo Primitivo; Clemente Romano.

\begin{abstract}
This article aims to demonstrate the pedagogical character that emerges from the First Letter of Clement Romanus to the Corinthians, in the 1st century AD, with regard to the virtues that this bishop of Rome defended for the ideal Christian formation. Clement Romano, third bishop of Rome, upon receiving news of dissent in the community of Corinth, decided to write this letter to issue advice and guidelines for the faithful of this Christian community and, in an attempt to convince them to resolve the relationship problems, he prepared a manual highlighting essential virtues in the formation of the Christian man of the period. In your letter, you can see examples of love for others, humility, faith, obedience, fraternity, unity and discipline. These virtues are explained in the letter in an educational way, using pedagogical resources, so that these followers of the new Christian belief obtain behavioral references and also become an example for new adherents.
\end{abstract}

Keywords: Education; Early Christianity; Clemente Romano.

\footnotetext{
${ }^{1}$ UEM-Universidade Estadual de Maringá.*E-mail: marciabolonhezm@ hotmail.com

${ }^{2}$ UTFPR-Universidade Tecnológica Federal de Apucarana - Pr
} 


\section{INTRODUÇÃO}

Estudar o cristianismo primitivo pode contribuir para a história da educação no que diz respeito a compreensão de como a atitude pedagógica de Clemente Romano contribuiu para a formação do homem cristão no primeiro século. Por esse motivo, uma pesquisa que considera esse autor e seu tempo histórico é relevante tendo em vista os conflitos comportamentais que Clemente Romano, na carta que escreveu para a comunidade de Corinto, procurou resolver e que, acabou por transformar-se em um manual cristão de formação, que até hoje é disponibilizado pela igreja contemporânea.

Segundo a tradição e a I Carta por ele redigida, jovens coríntios tinham se revoltado contra os dirigentes mais velhos, provavelmente motivados por disputas de poder e busca de maior representatividade. Sobre essas divergências, Clemente Romano (2001, p. 51) argumentou sobre os possíveis motivos ao alegar a existência de comportamentos invejosos.

Toda a glória e abundância vos foi dada, e cumpriu-se o que estava escrito: 'O amado comeu, bebeu, engordou, fortaleceu- se $\mathrm{e}$ recalcitrou'. 2. Daí surgiram a inveja, o ciúme, a querela e a sedição, a perseguição e a desordem, a guerra e a escravidão. Deste modo, insurgiram-se os indignos contra os dignos, os ignóbeis contra os nobres, os insensatos contra os ponderados, os jovens contra os anciãos (I CLEM., II, 1-2).

Assim, tendo em vista essa situação de dissensões internas em Corinto, na I Carta endereçada para a comunidade cristã, o padre apostólico exortou para que todos procurassem o caminho da unidade, obediência e harmonia cristã. Na efetivação de uma comunidade que Clemente Romano entendia como santa, ele elencou e discorreu sobre as virtudes que deveriam ser praticadas, como a fé, a humildade, o amor, a obediência, a solidariedade e fraternidade, a disciplina familiar e a união. Ele buscou uma forma de instruir os cristãos de Corinto por meio de uma formação cristã que considerasse a disciplina e a moral familiar. Sendo assim, poderíamos afirmar que Clemente Romano procurou resolver os conflitos apelando para a formação cristã? Quais princípios e meios utilizou para realizar seus objetivos? De que maneira ele entendeu a formação?

A partir desses questionamentos, pode-se compreender que as qualidades e práticas virtuosas do homem cristão, passavam em grande medida pela educação que acontecia na esfera familiar, no âmbito da comunidade e na busca de exemplos dignificantes para o 
homem daquele tempo. Em face disso, o objetivo principal deste artigo é discutir a proposta formativa cristã defendida por Clemente Romano na I Carta aos Coríntios. O princípio de que partimos é o fato de que as virtudes que ele entendeu como responsabilidade da família cristã e da comunidade teriam como finalidade solidificar o espírito cristão numa sociedade conflituosa. Por isso, elencamos as virtudes, a exemplo da disciplina familiar, da fé, do amor, da humildade, da obediência, da solidariedade e da união, porque elas deveriam repercutir na comunidade.

A I Carta aos Coríntios contém 65 Capítulos, com direcionamentos e conselhos dirigidos à comunidade de Corinto. Neles, podemos verificar a formação defendida por Clemente Romano para os cristãos, além de seus conhecimentos e o fato de pôr em pauta esboços teológico-doutrinais direcionados para a igreja que buscava sua identidade e efetivação. É importante ressaltar que Clemente Romano, ao escrever a I Carta aos Coríntios, teve como exemplo a Carta de Paulo de Tarso (5 d. C. - 67 d. C.), que também enviou uma epístola para a mesma comunidade, por volta de quarenta anos antes. Nela, prescreveu um novo comportamento a este homem atraído pelas mensagens cristãs. A I Carta aos Coríntios, portanto, possibilita o alcance de informações histórico-educativas sobre o ideal formativo de um povo.

Convém esclarecer, também, que a escolha do tema em questão justifica- se em um primeiro momento pelo interesse na formação instrucional do homem cristão no cristianismo primitivo. E, assim, a relevância do tema se dá na análise que se possibilita entender de que forma o homem antigo edificava a sua formação para superar as dificuldades do seu momento histórico. Em cada período os homens enfrentam transformações e são obrigados a pensarem novos caminhos de confrontação na tentativa de resolverem os conflitos e melhorarem suas condições vitais no seu contexto social e um desses caminhos foi a educação cristã edificada pela religião. A proposta de educação cristã surgiu como correção e esperança de superação para os seus adeptos e, diante da trajetória que conseguiram realizar, esse modelo de ensino encontra ressonância em todos os tempos, o que legitima a sua investigação.

$\mathrm{Na}$ pesquisa bibliográfica adotou-se como metodologia o estudo do texto fonte, considerando a relação dele com as circunstâncias do tempo histórico e da sociedade para quem Clemente Romano dirigiu seu texto. Dessa forma, é possível o acesso a uma série de conhecimentos, principalmente de fatos históricos que dão suporte significativo às análises do objeto de investigação e ao fenômeno formativo. Diante disso, foram feitas 
pesquisas e leituras de artigos e livros que auxiliaram para uma melhor compreensão dos aspectos da educação cristã na I Carta aos Coríntios de Clemente Romano.

A respeito da fundamentação optou-se em se analisar o objeto de estudo articulado ao processo de transformação da sociedade em que se insere, tendo-se em vista que "[...] as fontes foram e são condicionadas por fatores políticos, ideológicos, econômicos e tecnológicos, que restringem o seu acesso e uso pelos pesquisadores da História da Educação" (GONDRA; MACHADO; SIMÕES, 2017, p.248).

\section{OS PRINCÍPIOS FORMATIVOS DA I CARTA AOS CORÍNTIOS: O PAPEL DA FAMÍLIA NESSA FORMAÇÃO}

As ações realizadas por Clemente Romano objetivavam pacificar uma comunidade cristã conflituosa, movida, ao que parece, por posições discordantes entre os representantes mais jovens e os que se sentiam herdeiros da tradição apostólica. Em resposta às tensões, Clemente Romano chamou a atenção para a obediência aos líderes e o respeito ao Cristo, tanto quanto aos valores inspirados por ele. Entretanto, essa decisão tinha um aspecto mais profundo, a formação do cristão. Por isso, a Carta aos Coríntios manifesta um caráter pedagógico, porque revela o itinerário de valores, entre os quais o amor, a humildade, a fé, a unidade da comunidade, entre outros, além de especificar a importante missão da família nessas orientações.

Conforme a compreensão de Bultmann (2008) a pregação missionária cristã no mundo dos gentios não se baseou apenas no querigma de $\mathrm{Cristo}^{3}$. Os seguidores de Jesus anunciaram um Deus único tanto quanto defenderam uma conduta fundada em virtudes, semelhantes aos filósofos procuraram formar o homem ideal que desejavam mas, pautado sobre bases diferentes. Os pensadores gregos, discutiram uma perspectiva de homem que eles entendiam como pleno porque, pela formação, procuravam alcançar as virtudes necessárias para aperfeiçoar a si mesmos e o conhecimento sobre o mundo físico e político.

\footnotetext{
${ }^{3}$ Querigma - do grego, significa uma notícia de caráter público trazida por um arauto. No contexto da transmissão de fé, querigma é o primeiro anúncio de Jesus proclamando o Reino como uma nova e definitiva intervenção de Deua que salva com um poder superior àquele que utilizou na formação do mundo (MATOS, 2011, p. 50).
} 
Diferentemente, na doutrina cristã, os divulgadores da nova fé não se posicionaram na condição de filósofos (no sentido grego) porque a preocupação não era o livre exercício do pensar, outro aspecto importante: eles almejavam fazer com que a doutrina cristã prosperasse e se consolidasse como religião. Tinham como referência um Deus que amava o ser humano e, a ação moral ditada pelo credo cristão como prerrogativas principais, portanto, se ocupavam com as práticas cristãs, mais do que justificativas filosóficas. Desta forma, o propósito intrínseco da I Carta de Clemente Romano aos Coríntios foi estabelecer instruções para a comunidade e recomendar virtudes para consolidar uma conduta cristã exemplar, uma verdadeira educação ou paideia cristã tendo como fundamento a formação humana, levando o homem "[...] ao encontro e a um acolhimento de si mesmo e a uma magistratura (jurisdição, soberania e ajuizamento interno) quanto aos limites e possibilidades de seu agir" (SPINELLI, 2015, p. 29).

Movido por esse propósito, a preocupação de Clemente Romano, na Carta aos Coríntios, foi a formação/educação dos fiéis da comunidade para que vivenciassem os ensinamentos de Cristo e em Cristo tivessem o referêncial de conduta. Todas as virtudes que ele elegeu e defendeu tinham por fim um modelamento comportamental do homem ideal que ele entendia que deveria ser o homem cristão. Ao se posicionar dessa forma, ele estava contribuindo com a formação do homem cristão de Corinto (PEREIRA MELO, 2012).

Na concretização dos objetivos pretendidos, Clemente Romano encaminhou os cristãos para a realização de um propósito eclesiástico baseado na edificação da fé e nas virtudes necessárias ao homem cristão. Para isso, ele buscou exemplos do Antigo Testamento para justificar o que defendia. Entendeu que ele era "como livro-modelo para a ética" assim como exigia uma arte de interpretação e conhecimento perfeito e seguro daqueles que atingiram as profundezas do conhecimento divino (BULTMAN, 2008, p. 575). E, com esse conhecimento considerado perfeito, amparado pela fé, pelas obras e pelas virtudes que defendeu na Carta aos Coríntios, Clemente Romano estipulou um caminho para o novo homem imitador de Jesus Cristo. Nesse itinerário, uma das recomendações mais relevantes da qual utilizou era a ênfase na missão da família, tal como destacou no capítulo XXI, 8.:

Os nossos filhos partilhem da educação em Cristo, aprendam a força que possui a humildade e o que pode o puro amor de Deus, e como o 
seu temor é belo, grande e salvador para todos os que se santamente se convertem a ele com pensamento puro (I CLEM.,XXI, 8).

A formação e educação em Cristo exigia uma família unida, dentro da ordem religiosa, conforme os ensinamentos cristãos. E, concomitantemente, a casa da família seria o espaço privilegiado para a formação cristã, portanto, opadre apostólico era categórico em demonstrar aos coríntios que esse seria o melhor lugar para se ministrar aos filhos o que significava viver "em Cristo". "Para Clemente Romano, a origem da rebeldia dos jovens da comunidade de Coríntios seria o fato de que não foram instruídos "em Cristo" [...]" (PEREIRA MELO, 2012, p. 193).

Estes ensinamentos deveriam ser ministrados principalmente pelos pais que, para Clemente Romano, seriam as pessoas ideais para ensinarem estas virtudes aos filhos, bem como preservar a união que deveria reinar no núcleo familiar. Assim, se consubstanciaria o exemplo perfeito de unidade que reproduziria na comunidade cristã e, por consequência, também na sociedade em que viviam, ou seja, sob o Império Romano.

Também o instituto do matrimônio ajuda a ilustrar o peculiar mecanismo através do qual o cristianismo, que tendia a transcender o processo de mundanização, aprendeu a se defrontar com uma instituição fundamental como o matrimônio, cujos aspectos sociais vão da constituição da família à continuidade mesma da sociedade, através da geração e da educação de uma descendência (FILORAMO; RODA, 1997, p. 11).

Quando falamos em família no século de Clemente, é necessário entender que esse conceito era mais amplo do que o nosso atual núcleo familiar: pai, mãe, filhos e parentes. O núcleo familiar não era definido somente pelo parentesco como também pela relação de dependência e subordinação. O chefe de uma casa era responsável pela sua família e esperava obediência deles, assim como a dos escravos, a dos libertos que se tornavam clientes e a dos trabalhadores que os serviam (MEEKS, 1992). Nesse caso, ser integrante de uma casa equivalia ser parte de uma rede mais ampla de relações. Dentro da casa, havia uma cadeia vertical, mas não de todo unilinear que ligava papéis desiguais, desde o escravo até o pater familias, no elo mais íntimo. Igualmente, incluía laços entre cliente e patrão e ainda várias relações análogas, porém, menos formais de proteção e subordinação. Entre esta casa e outras, havia laçosde parentesco e de amizade que, muitas vezes, também acarretavam obrigações e expectativas. Essas ligações, entretanto, nem sempre eram necessariamente formais (MEEKS, 1992, p. 53). 
Deste modo, é possível entender o ato de Clemente Romano em privilegiar o núcleo familiar. Esse era o lugar perfeito para ministrar ensinamentos e comportamentos, uma vez que os cultos se realizavam em casas oferecidas, voluntariamente, pelas pessoas que se dedicavam à nova crença e instruíam os fiéis, conforme o modelo inspirado em Jesus Cristo.

A partir do momento que delimitou o ambiente familiar para iniciar e edificar a boa nova de Cristo, Clemente Romano enfatizou as virtudes que seriam alcançadas com o auxílio da disciplina formativa, uma formação direcionada pela família e, dentre as mais relevantes, constavam o amor ao próximo, a humildade, a fé, a obediência e a disciplina; também a união e a paz na busca de um homem pacífico e manso, respeitador das leis de Deus e das leis terrenas.

\subsection{A FORMAÇÃO PELO AMOR}

Entre as virtudes que caberiam ao cristão aprender, constava uma das mais fundamentais, o amor. Diferente dos gregos, que enfatizavam o amor físico,o conceito de amor no cristianismo estava caracterizado por outra forma de amar: era o amor ao próximo tal como, segundo a tradição, Cristo fez. Esse era um amor incondicional, em que se deveria acolher a todos os necessitados e, portanto, transcendia o aspecto carnal.

Segundo Silva (2010), foi Paulo de Tarso quem propôs uma interpretação para a palavra grega amor (eros) para uma outra forma de pensá-la e defini-la- Ágape que designa um tipo de amor que excede ao fraternal e é essencialmente divino e, segundo a proposta cristã, resume a essência de Deus e regula as relações com a divindade e com o próprio homem. Potanto, todo o código ético-moral cristão parte desta premissa: o amor (SILVA, 2010, p. 94).

Conforme as considerações de Theissen (2009), os valores fundamentais do ethos $^{4}$ cristão primitivo eram, fundamentalmente, o amor ao próximo e a renúncia ao status.

\footnotetext{
${ }^{4}$ A noção de "etos" indica uma moral conservada socialmente, tal como é característica para um grupo, uma profissão, um estado, uma sociedade. Não quer dizer que esse etos seja sempre praticado na respectiva comunidade, mas ele é reconhecido. Ele é o fundamento para adistribuição da honra e da desonra. Ele se expressa em sentenças e máximas e em uma tendência de comportamento (THEISSEN, 2009, 97).
} 
Estes conceitos representavam um comportamento comum que deveria guiar os cristãos, ainda que esses valores já estivessem presentes na tradição judaica. A respeito do amor ao próximo, os propagadores da nova crença iniciaram as suas convicções sobre o ethos conforme suas necessidades. Por exemplo, Paulo de Tarso, em 1Ts 3,12, apresentou o “amor mútuo e para com todos os homens" (BÍBLIA DE JERUSALÉM, 2002, p.2062), mas, diversamente, em Gl 6,10, ele elencou uma escala nesse amor por meio da qual exortou: "Pratiquemos o bem para com todos, mas sobretudo para com os irmãos de fé" (BÍBLIA DE JERUSALÉM, 2002, p.2038). Paulo de Tarso estava privilegiando os adeptos nas suas recomendações como se dissesse para praticar o bem, entretanto, quando estivesse entre um desconhecido e seu irmão de fé, a recomendação era a de escolher amar mais seu companheiro de fé.

Segundo a tradição, alguns exemplos protagonizados por Jesus Cristo parecem enfatizar o modo como o amor poderia ser compreendido e praticado. $\mathrm{O}$ acolhimento do estrangeiro, na parábola do bom samaritano e o da mulher adúltera, que foi protegida e perdoada por Jesus, ilustram a atitude amorosa dele. Representa a forma de amor ao próximo a partir do qual havia o acolhimento de todos sem distinção e a inexistência de atitudes discriminatórias por parte de Jesus Cristo. Pelo contrário, o amor era incondicional (THEISSEN, 2009).

A esse respeito Bultmann (2008) partiu do pressuposto de que o amor cristão recebeu características próprias. Para ele, o "servi-vos uns aos outros" (Gl 5.13) ganha seu caráter pelo acréscimo "mediante o amor".

Pois a liberdade que é própria do crente, ele a tem como escravo do Senhor ( $\$ 38,1)$, e não estando ele mesmo sob a Lei se tornou, por isso, um escravo dos que estão sob a Lei, e para os sem Lei, um sem Lei, porque ele está na Lei de Cristo. A Lei de Cristo (Gl 6.2), porém, é a exigência do amor. O carregar os fardos um dos outros, que é mencionado como o cumprimento dessa Lei, outra coisa não o é senão uma manifestação do servir uns aos outros pelo amor. É o amor que edifica a comunidade e que, por isso, exige a renúncia à autoridade (BULTMANN, 2008, p. 418).

Desta maneira, o sentido do amor ao próximo, conforme os ensinamentos deixados por Jesus Cristo, recebeu conotações diversas, de acordo com as interpretações que os propagadores se apropriavam para divulgar a nova crença. Cada um possuía uma visão que se distanciava ou não do ethos da nova religião. E, na compreensão de Clemente Romano, a instrução da comunidade pressupunha a formação desse valor. Embora 
compreendesse a dificuldade dessa tarefa, estabeleceu como condição a punição dos faltosos e a correção deles. No capítulo LIX,1, ele afirmou: "Mas se alguns desobedecerem aos conselhos que por nós Ele vos dirigiu, saibam que incorrerão em falta e em não pequeno perigo" (I CLEM, LIX, 1.). Portanto, o castigo corretor era uma maneira"amorosa" de impedir faltas graves. Assim, Clemente Romano reitera no cap. LI. 2 o fato de que a vida deve implicar no amor como também no temor: "Pois aqueles que vivem uma vida em temor e amor preferem sofrer o desprezo a comprometer a concórdia que bela e justamente nos foi transmitida" (I CLEM, LI,2). Ele sugere, em seu discurso, outra forma de amor: aquele que se remete aocomportamento de Jesus Cristo. No capítulo XLIX, Clemente Romano destaca esse amor apresentando o vínculo dele com Deus, a sua grandeza e a concórdia que ele promove.

1. Aquele que tem amor a Cristo, cumpra os mandamentos de Cristo. 2. O vínculo do amor de Deus quem o poderá narrar? 3. A grandeza da sua beleza, quem será capaz de a exprimir? 4. A altura a que nos guinda o amor é inefável. 5. O amor une-nos intimamente a Deus. O amor cobre a multidão dos pecados. O amor tudo suporta, o amor é paciente. No amor não há nada devulgar nem de orgulho. $O$ amor não se divide. $O$ amor não fomenta revolta. $O$ amor tudo faz em concórdia. Foi no amor que todos os eleitos alcançaram a perfeição. Sem o amor nada é agradável a Deus. 6. Foi no amor que Deus nos atraiu a si. Foi por causa do amor, que Jesus Cristo, nosso Senhor, por vontadede Deus, deu seu sangue por nós, sua carne pela nossa carne e a sua alma pelas nossas almas (grifo meu) (I CLEM. XLIX, 1-6).

Ao enfatizar o amor, ele descreve-o em sua grandeza porque foi concebido pelo Cristo. Amar incondicionalmente seria, na compreensão de Clemente, uma condição que promove o bem comum, em detrimento de si. O amor cristão - ágape se consubstanciava no acolhimento dos desamparados, dos alijados da sociedade, dando proteção a todos indistintamente. Para corroborar essa forma de amor, Pereira Melo (2012) considerou o fato de que as atitudes dos coríntios nãoeram consideradas compatíveis com $\mathrm{o}$ comportamento "em Cristo", com a disciplina "em Cristo". Por isso, ele lançou mão de outro conceito grego - Christô agogê, ou seja, uma disciplina ou guia cristã, cuja finalidade era determinar uma conduta desejável, ideal e própria do cristão, orientada para o cumprimento dos mandamentos "em Cristo" [...] a preocupação foi mostrar aos coríntios que eles precisavam retomar um comportamento "em Cristo e conhecer e vivenciar um ágape cristão, uma disciplina “em Cristo” (PEREIRA MELO, 2012, p. 194). 
Conforme as convicções cristãs, Clemente Romano procurou fundamentar sua proposta no comportamento de Jesus Cristo, tido como modelopara o novo homem. Clemente Romano exaltou este modus vivendi para a comunidade de Corinto porque considerou que seus adeptos deveriam seguir os passos de seu mestre. E, nesse sentindo decidiu sobre o amor corretivo, que acolhe a todos aqueles que se arrependem e estão dispostos a se submeterem as normas das comunidades.

Ao propor um modelo formativo que tinha Cristo como modelo, Clemente Romano destacou o valor do amor como uma virtude fundamental que promove a paz e a concórdia. Por isso, ele aconselhou os revoltosos a saírem da comunidade, que assumissem a culpa e, de forma resiliente, abandonassem os seus cargos e acatassem as ordens da comunidade.

Quem, pois, de vós é generoso? Quem de vós é compassivo? Quem de vós transborda de amor? 2. Que diga: se a revolta, a querela e os cismas são por minha causa, cedo o meu lugar. Saio daqui, para onde quiserdes, e faço o que for determinado pela comunidade. Que o rebanho de Cristo viva em paz com os presbíteros que foram constituídos em autoridade. 3. O que assim fizer receberá grande glória em Cristo e em qualquer lugarserá bem recebido. De facto, ao Senhor pertencem a terra e a sua plenitude. 4. Assim actuaram e actuarão os que levaram uma conduta digna de Deus, da qual nunca há que arrepender- se (I CLEM, LIV. 14).

Ao que parece, essa postura assumida por Clemente Romano sugere que havia membros comunitários que não estavam dispostos a seguir os ensinamentos de seu mestre. Provavelmente, Clemente Romano estava defendendo apenas a integridade da comunidade e, ao recomendar a saída dos membros rixosos, Clemente Romano está evocando o amor corretor para preservar a integridade da comunidade e de seus membros, instaurando a obediência e submissão a doutrina cristã como uma forma de exercício de humildade.

\subsection{O PAPEL DA HUMILDADE E DA FÉ}

Entre os valores mais reconhecidos e difundidos pelo cristianismo, constam a humildade e a fé. Para Clemente Romano, eles são fundamentais na constituição do 
homem cristão. No caso da humildade, na tradição sinótica ${ }^{5}$, era entendida como virtude social e tinha como pressupostos algumas premissas. Na primeira delas, "a interpretação do agir de Deus à luz do axioma de mudança de posição como humilhação e elevação salvíficas". Como se pode compreender, sobretudo quando se considera a palavra do evangelista Lucas $(1,52)$, "Deus faz valer sua salvação à medida que ele derruba dos tronos os poderosos e eleva os humildes". E essa mudança de status vamos ver no nascimento do Messias, pois ao ser gerado por uma mulher simples, do povo, extrai-se uma mensagem em relação ao novo rei, em que ocorre uma transformação na visão que havia sobre o conceito de humilhação que passou a ser vista como elevação. Um olhar de esperança na grande mudança escatológica que viria a acontecer um dia, em que todos seriam irmãos (THEISSEN, 2009, p.112).

Uma segunda premissa para o desenvolvimento deste conceito de humildade como virtude pode ser compreendido como um ideal humano de soberano a que pertence a autolimitação do senhorio mediante a renúncia ao status. Ela é traduzida na figura de Jesus Cristo entrando em Jerusalém montadonum jumento e o Evangelho de Marcos (10, 45) sugere que o filho do Homem não veio para ser servido, mas para servir a todos com a doação da própria vida. Nesse caso, ele é tanto um modelo para seus discípulos quanto um antítipo para os governantes terrenos, que oprimem as nações e abusam do poder contra as pessoas (Mc 10,42). Assim, na tradição sinótica, a humildade é a "renúncia ao status", o que se consubstancia na verdade a uma conveniência ao seu status inferior mediante a submissão, sem que se veja nisso uma virtude, conforme as palavras de Theissen (2009). Para este estudioso, a "humildade é imitatio da soberania que voluntariamente renuncia ao status. Humildade é virtude dos poderosos" (THEISSEN, 2009, p.113).

Em relação a esse conceito de humildade como virtude dos poderosos, este contrasta com o que a nova crença quer para este novo homem. Conforme argumenta Clemente Romano (I CLEM, XVI, 1), inspirado pelo NT, essa virtude deve ser uma atitude comum na comunidade que se está em formação. Os homens, imitadores de Jesus Cristo, devem perseguir uma conduta modesta, mesmo sendo de uma posição superior, respeitando o seu semelhante, seja ele pobre, rico, doente e aflito, sem prejulgamentos e

\footnotetext{
5 Tradição sinótica - essa palavra sinótica indica com que facilidade Mateus, Marcos e Lucaspodem ser postos em colunas paralelas e vistos sinoticamente, isto é, em um relance (CROSSAN, 2004, p. 61).
} 
com respeito mútuo entre os homens. E, assim, Clemente Romano exaltou que esta virtude era uma maneira de se comportar dignamente tanto na comunidade como nas relações com a sociedade. Tendo em vista as desigualdades no século I a orientação cristã para superação das dificuldades sociais era a humildade, seja pela renúncia ao status daqueles que exerciam cargos superiores, seja pela consideração aos que eram inferiores em relação às comunidades cristãs. Entre os cristãos havia também pessoas mais abastadas, talvez uma minoria, fica subentendida esta preocupação com os mais pobres que aderiam à nova crença e necessitavam de amparo na reunião cristã e na sociedade romana.

Tais aspectos sugerem que Clemente Romano orientou a prática da humildade aos coríntios para as autoridades da comunidade e para os governantes quando diz na oração final no capítulo LX que a paz e a concórdia são próprias dos que praticam a fé, principalmente aqueles que representam a comunidade

4. Dá-nos concórdia e paz a nós e a todos os que habitam a terra, como as deste aos nossos pais, que te invocaram santamente na fé e na verdade; para que obedeçamos ao teu omnipotente e santo nome e aos olhos das autoridades que nos governam (I CLEM., LX, 4).

De acordo com Pereira Melo (2011) é provável que Clemente Romano tenha conclamado aos coríntios a praticar a humildade, o amor e a harmonia, além do respeito e tantas outras virtudes, para que a igreja realizasse o seu fim aqui na terra. Para esse autor, afinal, não era outro o comportamento esperado daqueles que foram chamados a exercer essa condição especial, dádiva obtidapor meio de Cristo. E o maior exemplo que Clemente Romano destacou foi a humildade de Jesus Cristo, quando ele descreve a previsão de Isaías, no AT, sobre como seria a humildade oriunda do mestre neste mundo.

Não há dúvida de que Cristo é dos humildes e não dos que se rebelam contra o seu rebanho. 2. O ceptro da majestade de Deus, o Senhor Jesus Cristo, não veio com o clamor da jactâncianem com fausto, ainda que tivesse poder, mas humilhou-se como dele referiu o Espírito Santo18, que diz: 3. Quem, Senhor acreditou na nossa palavra? E a quem se revelou o braço do Senhor? Nós o anunciámos na sua presença: "como uma criança, como raiz que dentro da terra anseia por água”. Ele não tem aspecto nem glória: nós vimo-lo sem aspecto nem beleza; mas o seu aspecto era desprezível, comparado ao dos homens; era um homem de dores e sofrimento e experimentado em suportar fraqueza, porque o seu rosto se encontrava completamente desfigurado, desonrado e depreciado. [...] (ICLEM., XVI, 1-3). 
Assim sendo, segundo consta os relatos bíblicos, Jesus Cristo é apresentado como um ideal humano de soberano, pois se apresenta também com humildade, renunciando ao seu status, (Zc 9,9= Mt 21,5; cf. Jo 12,15). Ele é o rei humilde, embora fosse considerado o filho de Deus e, nessa condição, poderia exercer todo o seu poder divino, mas renuncia a ela até a extrema humilhação na cruz (THEISSEN, 2009, p.113).

Conforme ressalta no capítulo XVI; 1, exemplificando a humildade de Cristo, que deveria ser imitada pelos membros das comunidades:

Cristo está entre os humildes, e não entre aqueles que se sobrepõem ao seu rebanho. 2. O Senhor Jesus Cristo, cetro da majestade de Deus, não veio, embora pudesse, no alarde da arrogância ou da soberba, mas humilde, conforme o Espírito Santo havia dito sobre ele ${ }^{6}$ (I CLEM., XVI, 1).

As considerações de Clemente Romano para justificar a humildade como valor, parte dos relatos bíblicos sobre o nascimento de Jesus, conforme narrado nos quatro Evangelhos. Nestes textos sagrados, os relatos indicam que Jesus Cristo veio ao mundo numa manjedoura e sua mãe deu à luz num lugar simples, cercada por animais. Ele não nasceu em um palácio, o que aludiria para uma condição de nobreza. Os relatos bíblicos, ao contrário, enfatizam, o lado humilde da humanidade de Cristo e, assim também deveria ocorrer com os cristãos: deveriam agir com humildade e se posicionar ao lado dos que sofriam e não possuíam bens.

Sendo assim, irmãos, sejamos humildes de coração, pondo de parte toda a vanglória, cegueira, insensatez e ressentimentos, e pratiquemos o que está escrito. De fato, o Espírito Santo diz: "Não se glorie o sábio, na sua sabedoria, nem o forte na sua força, nem o rico na sua riqueza, mas quem se gloria, glorie-se no Senhor, no procurar que Ele não só faz o juízo como também a justiça". Lembremo-nos, sobretudo, das palavras do Senhor Jesus ensinava, quando pregava a benignidade e a longanimidade (I CLEM, XIII, 1).

De tal modo a humildade foi um recurso usado por Clemente Romano para atingir um ideal de homem com conhecimento e fé em si mesmo. Provavelmente, era uma forma de auxiliar este homem a se preparar para uma vida simples, como foi a do maior modelo

\footnotetext{
${ }^{6}$ Is. 53, 2-12 faz parte do quarto canto do Servo do Senhor (Is 52,12 -53,12). Esse texto constitui uma referência basilar da teologia messiânica dos primeiros autores cristãos. Cf. Justino, Diálogo XIII, 2-9; I Apol L, 5 (LAMELAS, 2001, p. 75).
} 
para eles, Jesus Cristo. A ideia parece ser a de que os cristãos deviam viver na comunidade pacificamente, com uma conduta que não os prejudicasse na convivência, sobretudo em relação à política do Império Romano. Essa foi uma maneira de Clemente Romano educar e formar a comunidade, uma vez que muitos não tinham acesso a uma instrução, moral ou intelectual.

Entretanto, embora o amor e a humildade fossem relevantes na composição dos valores pretendidos, eles pressupunham outros, entre os quais a fé. Ela é considerada um dos princípios fundamentais da doutrina cristã. A fé tem centralidade no conjunto dos valores difundidos pelo cristianismo. Sobre esse assunto, segundo os relatos de Ruiz Bueno (2002) a carta de Clemente Romano, enfatiza o fato de que "[...] apenas aqueles que não vivem a fé podem imaginar uma divisão na alma do crente, uma luta ou agonia entre o fato íntimo da fé e a cerca protetora da autoridade" (RUIZ BUENO, 2002, p.130). A fé para Clemente Romano e para os cristãos é o ponto crucial para todos que estão seguindo os ensinamentos de Jesus Cristo. A definição de fé para esse padre apostólico, conforme ressaltado nos capítulos XXX1.2 XXXII e XXXIV 3., é uma verdadeira inspiração e formação provenientes da sabedoria divina e, por meio dela, se alcança a vida eterna com Deus. As obras e a caridade também são imprescindíveis e, ao recomendar as obras junto com a fé, Clemente Romano emite as coordenadas para o novo cristão se mostrar digno da salvação em Cristo. Contudo, no capítulo XXXII. 3, constatase o alerta de Clemente Romano:em primeiro lugar vive-se pela vontade de Deus e, em segundo lugar, com um comportamento digno para agradar a Deus.

Sendo assim, todos estes não foram glorificados nem celebrados por si próprios, nem por obras suas ou feitos que executassem, mas por vontade dele. 4 . Sendo assim, também nós, tendo sido chamados pela sua vontade em Cristo Jesus, não nos justificamos a nós próprios pela nossa sabedoria, nem pela inteligência, piedade ou obras que fizéssemos emsantidade de coração, mas pela fé, pela qual Deus, o Todo Poderoso, a todos justificou, a quem pertence a glória pelos séculos dos séculos. Amém (I CLEM., XXXII, 3).

Em contrapartida, é possível que Clemente Romano estivesse defendendo veementemente os ensinamentos que redigiu na carta. Entretanto, ele não elencou nenhuma dessas virtudes como preponderante sobre as demais. Ele exaltou vários comportamentos e mandamentos para o homem cristão, no conjunto de valores que tomou como preponderantes. Entretanto, também compreende que a vontade de Deus é que vai decidir quem será digno de entrarno reino dos céus com Ele e com seu filho Jesus Cristo. 
Aceitai o nosso conselho e não vos haveis de arrepender. Pois Deus vive, e vive o Senhor Jesus Cristo e o Espírito Santo, a fé e a esperança dos eleitos, porque aquele que, em espírito de humildade e perseverando na moderação, praticou os preceitos e mandamentos dados por Deus, esse será alistado e contado no número dos salvos por Jesus Cristo, pelo qual a ele a glória pelos séculos dos séculos. Amém (I CLEM., LVIII. 2).

Além do mais, advertiu os coríntios, com muita autoridade e incentivo ao comportamento por meio da fé e obras, a fim de que cumprissem com os mandamentos e realizassem as obras necessárias. Igualmente, ele demonstrou que, para isso, haveria de ter obediência e caridade na comunidade de Corinto na boa nova que se iniciava.

Sendo assim, que devemos fazer, irmãos? Havemos de negligenciar as boas obras e abandonar a caridade? Nunca Deus permita que tal nos suceda; pelo contrário, apressemo-noscom todo ardor e coragem a levar a cabo toda a boa obra. 2. Pois o próprio Criador e Senhor de todas as coisas também se regozija com as suas obras (I CLEM., XXXIII, 1).

Para respaldar seu ensinamento, Clemente Romano cita como exemplo de obediência e fé, a prostituta Raab. A partir disso, enfatizou a salvação dela com base na sua boa ação. Raab não era uma seguidora do Deus judaico, mas teve boas obras, como Clemente Romano destacou:

1. Por causa da fé e hospitalidade, salvou-se Raab, denominadaa prostituta. 2. Quando Josué, filho de Nun, enviou secretamente espias a Jericó, chegou ao conhecimento do rei da terra que eles tinham chegado para reconhecer o seu país, e mandou homens que os prendessem, para serem sentenciados à morte. 3. Mas a hospitalidade de Raab recebeu-os em casa e ocultou-os no terraço, com palha de linho (I CLEM, XII, 13)

Clemente Romano explica que, em Raab, não havia só fé, mas também ação, virtudes essenciais para se alcançar a verdadeira sabedoria para o cristão. Não foi por acaso que o autor escolheu o exemplo de Raab, porque nele estão contidos o que os homens sentiam, pois, se uma prostituta alcançou graça e salvação, todos aqueles que se convertessem à nova doutrina, independente deseus feitos passados, teriam uma nova chance de se reconciliarem com Deus e com a comunidade cristã.

Com Jesus Cristo como modelo, o cristão deveria se comportar de uma forma a respeitar o próximo como se fosse sua própria família, numa relação pautada no afeto e na fraternidade universal. Não seria mais suficiente somentea fé, mas a fé teria que ser 
acompanhada de boas obras, e o vínculo da perfeição dessas boas obras era o amor. Esse valor é, para o cristão, indispensável na composição de uma comunidade fraterna.

\subsection{A DISCIPLINA E O AMOR CORRETIVO}

Para além da fraternidade como um valor essencial, Clemente Romano destacou outro não menos importante, na composição do perfil cristão que desejava formar, a disciplina. A função dela era a de instruir nos padrões cristãos a partir de um rigor comportamental, segundo um conjunto de regras. Ela também implica um nível de coerção a fim de que transgressões sejam evitadas. Nesse aspecto, a formação cristã conferiu importância fundamental no papel da família em moldar o comportamento cristão pretendido desde a mais tenra infância, mas também exortou os mais velhos e os dirigentes das comunidades para a manutenção da ordem da religião cristã. A pureza da comunidade não tem como finalidade apenas a salvação individual, mas de todos os adeptos, pois o propósito é ser uma comunhão dos santos como um todo.

O enfoque numa conduta cristã digna perpassa por uma disciplina que foi exortada por meio de advertência ou castigo, educando os indivíduos e até excluindo membros indignos. A responsabilidade por esta disciplina se dirigiu a todos os membros da comunidade e Clemente Romano alertou em 1Clem 56.2 essa importância: "admoestai uns aos outros ou reciprocamente". Especialmente pais e mães tinham o dever de educar a prole ou a família (1Clem 21.8) e, por conseguinte, os mais velhos também tinham esse dever para com os mais jovens (1Clem 21.6). Aos dirigentes cabia a missão de educar e repreender (1Clem., 7.1) (BULTMANN, 2008, 684).

Assim, os cristãos foram alertados na carta sobre as virtudes e caminhos pelos quais o cristão deve trilhar, capítulo XXI, 6-7:

Reverenciamos o Senhor Jesus cujo sangue por nós foi derramado. Respeitemos os nossos superiores. Veneremos os presbíteros. Inculquemos aos novos a disciplina e o temor de Deus. Eduquemos as nossas esposas no bem. 7. Adquiram o amável costume da pureza, demonstrem um puro desejo de docilidade, evidenciem a discrição de sua língua com o silêncio, ofereçam o seu amor não sob forma de provocações, mas santamente e por igual a todos os que temem a Deus (I CLEM.,XXI, 6-7). 
Na segunda parte da carta, no capítulo XXXVII, Clemente Romano fez mais uma admoestação sobre a disciplina ao proferir a comparação da ordem na comunidade com a organização militar, ensinando sobre a obediência devida aos superiores. É provável que esse fosse um exemplo que provinha do exército romano, uma organização que inspirava ordem e disciplina. No capítulo XXVII,é citada essa ordenação com veemência.

Militemos, pois, corajosos irmãos, com perseverança, nas suas irrepreensíveis fileiras. 2. Consideremos como os soldados, subordinados às nossas autoridades, executam pronta, ordenada e docilmente as suas ordens. 3. Nem todos são perfeitos, nem todos os tribunos, nem todos os centuriões, mas cada um, no lugar que lhe compete, executa as ordens do rei e das autoridades (I CLEM., XXVII, $1-3)$.

Clemente Romano demonstrou com este exemplo a obediência exigida para um servo do Senhor e disciplinado nos mandamentos cristãos e, ao descrever exemplos pagãos, exaltou a submissão de reis que se sacrificaram pela comunidade, como no capítulo LX. I.

\begin{abstract}
A este propósito, poderíamos também aduzir exemplos de gentios: muitos reis e chefes, em ocasião de calamidade, depois de consultarem o oráculo, entregaram-se à morte, para libertarem os cidadãos mediante o seu próprio sangue. Muitos outros saíram das suas cidades, para pôr fim à rebelião. 2. Sabemos que, entre nós, muitos se entregaram às cadeias, para resgatarem outros; muitos ainda se entregaram à escravidão e, com o seu preço, mataram a fome a outros (I CLEM., LV, $1-2)$.
\end{abstract}

Clemente Romano, ao descrever exemplos pagãos, os mais próximos dosquais podia utilizar, estava moldando o homem cristão para a nova crença e o convívio social, e esse homem deveria aceitar com humildade e fé numa vida eterna, o que lhe foi designado como destino de vida no seu presente, sem almejar uma vida melhor a não ser o que fosse determinado pela crença e pela vida. Clemente Romano estava formando esse homem para a obediência na família, resignado ao seu quinhão, além de conduzir para a vida em comunidade.

Nela, estaria pronto para trabalhar na obra cristã e no seu sustento e, desse modo, o trabalho adquire uma conotação de missão, serviço que deveria ser desempenhada e dedicada ao Senhor. A ambição era considerada um pecado aos olhos do Senhor, "Os cristãos primitivos estavam mortos para os negócios e os prazeres do mundo [...]" (GIBBON, 2012, p. 50). 
Assim, Clemente Romano adverte que o bom trabalhador recebe o pão com a cabeça erguida, enquanto o preguiçoso e o negligente deveria sentir vergonha de seu comportamento. Ele declarou que Deus é quem retribui a cada um segundo a sua boa obra, exortando que cada um deve entender o trabalho como uma forma de serviço a Deus e à comunidade. $\mathrm{O}$ cristão, então, deveria ser disciplinado no que diz respeito ao trabalho desenvolvido. De certa maneira,o trabalho na perspectiva de Clemente Romano, enquanto serviço missional, promove a solidariedade e a união na comunidade.

\subsection{A UNIÃO NA COMUNIDADE}

Em relação à comunidade de Corinto, Clemente Romano não se referiu de modo diferente daquelas virtudes advertidas para a família cristã. É nas relações entre seus membros que ele advertiu sobre os ensinamentos cristãos: indicou a conduta que a comunidade tinha antes das discórdias que ele tentou superar e,capítulo II, 3, mencionou a fraternidade como condição fundamental para estabelecer a concórdia comunitária.

Combatíeis, dia e noite, pelo interesse de toda a fraternidade, a fim de que na piedade e na concórdia de sentimentos se salvasse o número dos seus eleitos. 5. Éreis sinceros, simples epuros e sem rancor para com os demais. 6. Toda rebelião e todoo cisma era-vos abomináveis. Condoíeisvos com os pecados dopróximo (I CLEM., II, 4-5).

Essa postura de Clemente é reveladora porque demonstra as contradições existentes na comunidade para a qual ele endereçou a carta, recomendando os meios pelos quais seria possível construir laços comunitários sólidos. Para ele, a comunidade necessitava ser alertada sobre os atos que estavam perturbando o andamento da missão cristã e Clemente Romano utilizou de um tom fraterno por meio do qual comparou as crises dos irmãos de fé com um combate em que devem ser superados as coisas vãs para experenciar uma vitória gloriosa.

VII. Escrevemos estas coisas, caríssimos, não só para vos admoestar, mas para delas nos recordarmos nós próprios pois nos encontramos na mesma arena e o combate que nos espera é o mesmo. 2. Por isso deixemos as vãs e inúteis preocupaçõese sigamos a gloriosa e venerável norma da nossa tradição. 3. E vejamos o que é bom, o que é agradável, o que é aceitável aos olhos daquele que nos criou (CLEM., VII, 1-3). 
Para reforçar a união na comunidade, Clemente Romano recomendou o exercício dos ensinamentos de Cristo, entre eles a santidade, a justiça o carismada fé e a sabedoria necessária para discernir as ações.

Posto que haja muitas portas abertas, esta porta da justiça é a de Cristo, pela qual são bem-aventurados todos os que entrarame caminharam rectamente em santidade e justiça, realizando tudo tranquilamente. 5 . Que um tenha o carisma da fé, outro seja forte em explicitar o conhecimento, outro seja sábio no discernimento dos discursos, outro seja casto nas obras. 6. Pois quanto maior pareça ser, tanto mais humilde deve ser e procurar o bem comum e não o próprio (I CLEM., XLVIII, 4).

Para enfatizar uma conduta que traga união para a comunidade, no capítulo XXXVII, 5, da carta, Clemente Romano utilizou uma metáfora, também mencionada por Paulo de Tarso, na sua I Carta aos Coríntios, cap. XII, 12-27. Nessa metáfora, Paulo de Tarso faz uma analogia com o corpo humano na qual enaltece a união dos irmãos em Cristo equiparando essa unidade essencial coma perfeição do funcionamento do corpo humano. Da mesma maneira, ClementeRomano recomendou aos coríntios a devida observação do corpo humano e retirar dele a devida harmonia.

Reparemos no nosso corpo: a cabeça sem os pés não é nada, nem os pés sem a cabeça. Os membros menores do nosso corpo são os mais necessários e úteis a todo o corpo. Contudo é necessário que todos conspirem para um mesmo fim e se submetam a uma autoridade para que o corpo todo se salve (I CLEM., XXXVII, 5).

Dessa maneira, Clemente Romano dispõe desse gênero didático para reforçar a unidade e a necessidade de subordinação dos membros da comunidade à hierarquia legitimamente constituída da comunidade, conforme o exemplo. Evidenciou a importância da colaboração e da harmonia entre aqueles que têm maior ou menor relevância, pois um não pode sobreviver sem o outro. Todos em união proporcionam o funcionamento perfeito para um corpo, seja o biológico, ou o social, no caso dos cristãos, seja o espiritual, no caso da comunidade cristã (PEREIRA MELO, 2012, 198).

Conforme é possível entender na redação de Clemente Romano, as exortações em relação à comunidade transmitem uma forma de reuni-la num objetivo comum, o de formar a nova crença de forma ordenada e estruturada para a comunhão de fé. O meio para a realização desse objetivo era a instrução e a formação de seus adeptos, cada um na sua função. Conforme a compreensão de Trevijano (1994), o objetivo da carta de 
Clemente Romano foi expressamente eclesiológico $(63,2)$, uma vez que as admoestações morais, na figura de "catálogos de vícios e virtudes com relatos exemplares, estavam a serviço desse interesse para assegurar a paz e a concórdia como um valor social, eclesiológico" (TREVIJANO, 1994, p. 21). Ressalta-se que esta é uma das finalidades de Clemente Romano, mas não a primordial, uma vez que asrecomendações principais perpassam a fé, a humildade, o amor, a fraternidade e união, com o propósito de formar e educar o homem cristão para a nova crença.Entende-se que a Igreja se configura "como estrutura organizada com autoridade institucional" (TREVIJANO, 1994, p.21), mas não naquele momento, em que se organizavam as comunidades de forma instrucional, sem um objetivo eclesiástico como depois, nos séculos seguintes, que se verificou.

Além do mais, nos ensinamentos e analogias que Clemente Romano recomendou a esta comunidade com problemas, enfatizou o fato de que fosse privilegiado também a educação coletiva, tendo como modelo o ordenamento da natureza física e humana. Esta foi a primeira finalidade da carta de Clemente Romano: instruir e formar o homem que se encontrava num abismo social, não sabendo que rumo tomar no Império Romano. Havia uma situação de religiões em confronto enquanto outras surgiam, o judaísmo lutando por manter Israel vivae cultos politeístas, um ambiente perfeito e sugestivo para uma nova crença que oferecesse novas referências aos romanos.

Assim sendo, em face do exposto, importa considerar a importância de Clemente Romano, situado nas origens do cristianismo e, nesse contexto, as contribuições que ofereceu na elaboração de um perfil formativo. Em primeiro lugar, Clemente Romano está demonstrando que o seu objetivo é conduzir os cristãos para uma unidade comunitária a partir dos valores sugeridos por ele e que cumpriria à formação concretizar. Quando Clemente Romano redige a sua carta mencionava a paideia, que significava a maneira que o pecador possuía para se tornar um homem melhor, que seria passar por uma mudança de espírito mediante o castigo sofrido aqui mesmo, neste mundo. Somente assim, ele se tornaria o homem desejado pela formação cristã. Nesta perspectiva, ele acreditava na "paideia de Cristo" e a oferece ao homem de Corinto como "a grande força protetora na vida do cristão". Ele também pressupunha o reconhecimento destes homens virtuosos à existência do ágape cristão, em quebuscariam o bem comum em detrimento deles mesmos (JAEGER, 2014, p. 35).

Em segundo lugar, na carta que escreveu, Clemente Romano sempre alerta para que os cristãos vivam como irmãos em Cristo, uma súplica que se torna uma constante. $\mathrm{O}$ 
que podemos compreender é a defesa de um sentimentofamiliar necessário para edificar o homem nas leis cristãs e na obediência das virtudes já elencadas. Elas contribuiriam para definir um comportamento inclinado para o divino, para a santificação, como se pode constatar no capítulo II. 1.

Todos pensáveis humildemente e não vos vangloriáveis. Preferíeis obedecer a ser obedecidos; dar o próprio a receber; contentáveis-vos com as provisões que Cristo vos fornecia para o vosso peregrinar; e escutando as suas palavras, guardávei-las carinhosamente no íntimo do vosso coração e conserváveis seus sofrimentos diante dos vossos olhos. 2. Assim, era-vos concedida a todos uma paz profunda e uma ânsia insaciável de bem-fazer; e sobre todos se estendia uma abundante efusão do Espírito Santo (I CLEM., II, 1).

Ao mencionar essa condição, a promessa era que uma vez que se submetessem aos direcionamentos propostos e obedecessem com fé e brandura, seriam preenchidos pelo Espírito Santo e teriam a vida eterna com Deus e Jesus Cristo no paraíso celestial, uma vida após a morte com todas as graças prometidas. Clemente Romano exaltou esses valores à comunidade de Coríntios, no capítulo I, ao recordar o comportamento nos caminhos da santidade que é, a rigor, o fim a que todos cristão busca.

Quem houve, pois, que vos tivesse visitado e não apreciasse a verdadeira virtude e firmeza da vossa fé? Não admirasse a sábia e consentânea piedade em Cristo? Não proclamasse a vossa generosíssima hospitalidade? e não felicitasse a vossa acabadae firme ciência divina? 3. Efetivamente tudo fazíeis sem preferência de pessoa; andáveis nas leis de Deus; éreis submissos aos vossos superiores; prestáveis a honra devida aos vossos anciãos; induzíeis os jovens a pensar o justo e o santo; exortáveis as mulheres a fazerem tudo em consciência irrepreensível, santa e pura, amando os seus maridos como convém e, andando na lei da obediência, ensináveis a cuidar da casa sábia e santamente (I CLEM., I, 2-3).

Diante disso, Clemente Romano compreendeu que o modelo ideal de homem era aquele que se adequasse aos ensinamentos advindos de Cristo e que foi divulgado pelos apóstolos, mesmo que amparados por exemplos clássicos. Assim, a formação moral foi um dos ideais perseguidos pelos cristãos. Nessa formação cristã, não havia espaço para a discórdia, pois, os exemplos deixados por Cristo, apontavam para a paz, a harmonia, a união e o amor, conforme afirmou no capítulo XIV, que ratificam estes comportamentos. 
Comportemo-nos uns para com os outros segundo a comiseração e a doçura daquele que nos criou. 4. Pois está escrito: os mansos habitarão a terra e os inocentes permanecerão nela, mas os que agem iniquamente serão dela exterminados.5. E volta a dizer: Vi o ímpio exaltado e elevado como os cedros do Líbano, mas ao passar já lá não estava; procurei o seu lugar, mas já não o encontrei. Guarda a inocênciae observa a equidade que são apanágio do homem pacífico (CLEM., XV, 2-5).

Isso posto, cumpre afirmar que o homem ideal pretendido por Clemente Romano era aquele que buscava alcançar a perfeição como homem cristão. Ele seria um modelo para os demais porque teria Cristo como exemplo santificador a partir do qual revela um comportamento humilde, piedoso e justo. A partir desta concepção, as virtudes que Clemente Romano elencou em sua I Carta serão referenciais para o fundamento educacional e formador do cristão. Era na família a forma como esse homem, a semelhança de Cristo, seria moldado e, depois, nas comunidades. Elas seriam extensões da família universal onde Deus é entendido como o grande pai e, como tal, todos seriam elevados à condição de irmandade. Com esses princípios, as ideias defendidas por Clemente Romano em sua Carta endereçada a Coríntios, se juntaram a uma tradição de pensamento que formou o cristianismo e, como tal, foi reveladora das contradições e dos valores que visavam superá-las. Por esse motivo, esse pensador cristão é fundamental para compreender um momento importante da história e o modo como, naquele momento, a educação foi convocada a atender os interesses e demandas da igreja.

\section{CONCLUSÃO}

Ao discutir a Carta de Clemente Romano aos Coríntios, escrita no séculoI d. C., podemos entender que a finalidade primordial foi a educação cristã proposta pelo padre apostólico para aquela comunidade, tendo como base a paideia grega já sistematizada pela filosofia grega. A partir da educação cristã, estabeleceu as diretrizes básicas para difundir o cristianismo nos domínios do Império Romano, um ambiente tido como opressor e autoritário para os cristãos, promovido por perseguições. Em face disso, Clemente Romano resistiu e estimulou a resiliência dos cristãos a partir das crenças que acreditava serem as corretas mediante a fé. Entre as formas que elaborou, constava o apelo 
aos aspectos e valores formativos que defendeu no tex to que enviou para uma comunidade que apresentava crises internas ressaltando o papel da família nessa formação.

O entendimento do modelo formativo elaborado por Clemente Romano partiu do fato de que a compreensão da educação cristã se alarga quando a pensamos inserida na dinâmica das relações sociais do autor em discussão. No caso desse padre apostólico, o estabelecimento do cristianismo no interior do Império Romano e em cidades gregas, a exemplo de Corinto, não foi livre de conflitos internos e crises. No enfrentamento delas, um novo modelo de homem e sociedade são propostos, o autor apostólico propôs uma formação cristã que efetivasse o modelo de cristão, o qual passava pela aquisição de comportamentos virtuosos.

$\mathrm{Na}$ efetivação das virtudes exigidas para o homem cristão, ele usou de artifícios para fortalecer a religião, entre os quais a de edificar um novo homem tendo como modelo a imitação de Jesus Cristo. Clemente Romano utilizou de muitas histórias da tradição cristã, inspiradas no judaísmo e não dispensou as tradições pagãs, tanto da filosofia clássica como das histórias disseminadas na cultura helênica quando elas lhes interessavam para justificar o que defendia. Sob o ponto de vista pedagógico, podemos entender que os recursos utilizados por Clemente Romano foram sistematizados com a finalidade de fortalecer os homens na fé/, no cultivo do espírito, na aceitação passiva de suas condições materiais e espirituais, na busca de formar um homem obediente, de fé, com amor ao próximo, humilde para se reconhecer pequeno diante da humanidade. E, assim, Clemente Romano destacou em sua carta, as virtudes para esse homem: o amor ao próximo, a fé, a humildade, a caridade, a fraternidade, a disciplina em Cristo, colocando a cargo da família a edificação e educação desses.

Assim, a I Carta de São Clemente Romano destinada à comunidade de Coríntios, é um importante recurso para compreender um momento bastante singular da história e, em especial, da educação cristã que se perpetuou por muitos anos, se aprimorando e se solidificando como uma forma de instruir e formar o homem ocidental.

\section{REFERÊNCIAS}

COWPER, B. H. The epistle of Clement of Rome to the Corinthians. With an introduction and notes by London: The Religious Tract Society, 1867 Disponível em: https://play.google.com/books/reader?id=BrRWAAAAcAAJ\&pg=GBS.PA2 
BÍBLIA de Jerusalém. São Paulo: Paulus, 2002.

BUltMAnN, R. Teologia do Novo Testamento. Tradução de IlsonKayser; revisão Nélio Schneider. Santo André: Editora Academia Cristã, 2008.

CARTA de são Clemente Romano aos Coríntios. Introdução de Roque Frangiotti In:

Página 23-72. Coleção Patrística. 2. ed. São Paulo: Paulus, 1995. v.1.

CLEMENTE ROMANO. Carta aos Coríntios. Introdução de Isidro P. Lamelas, Tradução de Luís Marques Alcalá: Lisboa, 2000.

FILORAMO, G.; RODA, S.. Cristianismo e Sociedade Antiga. Tradução de José Maria de Almeida - São Paulo; Paulus, 1997.

GONDRA, J. G.; MACHADO, M. C. G.; SIMÕES, R. H. (Orgs). História da Educação: matrizes interpretativas e internalização. Vitória: EdUFES, 2017. p.227271.

JAEGER, W. Cristianismo primitivo e Paidéia grega. Tradução de DanielCosta. Santo André: Academia Cristã, 2014.

JEFFEERS, J. S. Conflito em Roma: ordem social e hierarquia no cristianismoprimitivo. Tradução de Adail V. Sobral; Maria Stela Goncalves e Laureano Pelegrin. São Paulo: Edições Loyola, 1995.

MATOS, M. F. O Mistério Pascal na Homilia: Um Serviço daComunidade por meio da Liturgia da Palavra. USP- São Paulo, 2011. Dissertação apresentada no Mestrado em Liturgia da Pontifícia Universidade Católica de São Paulo - USP - em 2011. Disponível em: https://tede2.pucsp.br/bitstream/handle/18292/1/Marcelo\%20Froes\%20de\%2 0Matos.pdf. Acesso em 03/08/2021.

MEEKS, W. A. Os primeiros cristãos urbanos: o mundo social do apóstolo Paulo. Tradução de I. F. L. Ferreira. São Paulo: Edições Paulinas, 1992.

. As Origens da Moralidade Cristã: os dois primeiros séculos. Tradução de Adaury Fiorotti. - São Paulo: Paulus, 1997.

PEREIRA MELO, J. J. São Clemente Romano e sua Carta aos Coríntios: aspectos da educação cristã. Revista Brasileira de História das Religiões, ANPUH, Porto Alegre, ano V, n.13, maio 2012. Disponível em:

http://www.periodicos.uem.br/ojs/index.php/RbhrAnpuh/article/view/30258 Acesso em: 12 jan. 2020.

SOCIEDADE Bíblica do Brasil. Revista e corrigida, edição de 1995 da Sociedade 
Bíblica do Brasil. 2. impr. Rio de Janeiro: Casa Publicadora das Assembleias de Deus, 2019. Disponível em:

https://docer.pl/show/?q=Revista+e+Corrigida\%2C+edi\%C3\%A7\%C3\%A3o+ $\mathrm{de}+1995+\mathrm{da}+$ Sociedade+B $\% \mathrm{C} 3 \%$ ADblica+do+Brasil.+2.+Impr.+Rio+de+Jan eiro\%3A+Casa+Publicadora+das+Assembleias+de+Deus\%2C+2019. Acesso em: 12 jul. 2020.

RUIZ B. D. Padres Apostólicos Y apologistas griegos (S.II). Madrid: BAC, 2002.

SILVA, R. G. A. A formação do homem ideal em Paulo de Tarso: o amor como elemento formativo. Dissertação de Roseli Gall do Amaral Silva apresentada ao Programa de Pós-graduação em Educação da Universidade Estadual de Maringá. Maringá, PR: UEM, 2010. Disponível em:

http://www.ppe.uem.br/SITE\%20PPE\%202010/dissertacoes/2010_roseli_gall.pdf. Acesso em 27 jul. 2021.

SPINELLI, M. Herança Grega dos Filósofos Medievais. São Paulo: Hucitec, 2013.

THEISSEN, G. A Religião dos Primeiros Cristãos: Uma teoria do Cristianismo

Primitivo. Tradução de Paulo F. Valério. - São Paulo: Paulinas, 2009.

TREVIJANO E, R. Patrologia. Biblioteca de Autores Cristianos. Madrid: 1994. 